FLIES AND DISEASE, Volume II

Biology and Disease Transmission 



\section{FLIES AND DISEASE}

Volume II $\begin{gathered}\text { BIOLOGY AND DISEASE } \\ \text { TRANSUISSION }\end{gathered}$

BY BERNARD GREENBERG

Princeton University Press, Princeton, New Jersey 1973

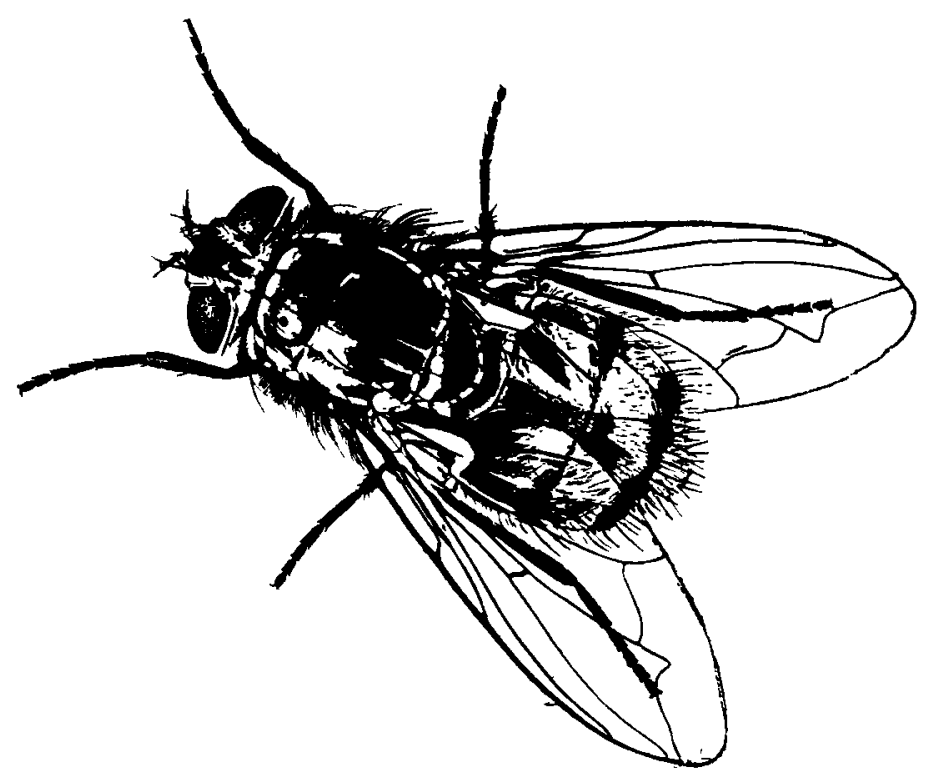


COPYRIGHT (C) 1973 BY PRINCETON UNIVERSITY PRESS ALL RIGHTS RESERVED No part of this book may be reproduced in any form or by any electronic or mechanical means including information storage and retrieval systems without permission in writing from the publisher, except by a reviewer who may quote brief passages in a review $L C$ Card 68 56310 ISBN 0-691-08093-3 Printed in the United States of America by Princeton University Press This book has been composed in Linotype Times Roman

Publication of this book has been arded by grants DA-MD-59-193-67-G9225, DADA-17-69-G-9225, and DADA-17-70-G-9313 from the US Army Medical Research and Development Command

Princeton Legacy Library edition 2019

Paperback ISBN: 978-0-691-61906-4

Hardcover ISBN: 978-0-691-65588-8 
To my children, Gary, Linda, Debbie, and Danny 
